owners of real property or a chattel real which is security for any debt. There are no other limitations upon the class of those who may file under Chapter $\mathrm{XII}$, except that the arrangements are primarily for secured creditors. $4^{\circ}$ Since the requirements of Chapter XII appear on the whole to be less stringent than those of Chapter $X$ it is very likely that the problem in the future will be the converse of the present one in that corporations will transfer their properties to individuals and attempt to proceed under Chapter XII.4r

Even though Chapter XII was expressly inserted in the bankruptcy act to remedy the plight of the individual debtor with real estate indebtedness, the debtor may still want to seek relief under Chapter $\mathrm{X}$. Insofar as the cases under $77 \mathrm{~B}$ held petitions as not filed in good faith when filed by corporations organized for that purpose, the failure to specifically outlaw such practice in the good faith section of Chapter X may mean that the practice is not disapproved. Although good faith is not defined, a minimum criterion has been set up so that good faith does not exist in the following fact situations. (I) If the creditors have acquired their claims for the purpose of instituting proceedings; (2) if adequate relief would be obtainable under Chapter XI; (3) if it is unreasonable to expect that a plan of reorganization can be effected; (4) if a prior proceeding is pending in any court and it appears that the interests of creditors and stockholders will be best subserved in such prior proceedings.42 Except for the second these statutory enactments represent prior case law under section $77 \mathrm{~B}$ which did not provide any criteria for determining good faith. ${ }^{43}$ Therefore, it can be contended that Congress did not intend to include under the concept of bad faith a corporation organized solely to take advantage of Chapter $\mathrm{X}$ as decisions on the instant point had been rendered prior to the drafting of the Chandler Act.

\title{
SOME ASPECTS OF THIRD PARTY BENEFICIARY CONTRACTS IN IILINOIS
}

In England, the third party beneficiary of a contract occupies a very definite, even if not an advantageous position. He cannot bring an action against the

${ }^{40}$ See $5_{2}$ Stat. 918 (1938), II U.S.C.A. $\$ 806$ (I), (6) (Supp. I938).

${ }_{41}$ Chapter XII does not have any good faith requirement. Furthermore there are no provisions which provide for the intervention of the Securities Exchange Commission. Also many of the disclosure provisions of Chapter $\mathrm{X}$ to safeguard the creditors in the formulation of a plan are absent. But Chapter $\mathrm{X}$ has more liberal provisions for the allowance of fees. Chapter XII is also speculative as to what may be deemed to be an interest in real property. Unsecured creditors can only be brought into the proceedings indirectly.

${ }_{42} 5_{2}$ Stat. 887 (1938), iI U.S.C.A. 8546 (Supp. I938).

${ }^{43}$ In re Philadelphia Rapid Transit Co., 8 F. Supp. 5 I (1934) aff'd 73 F. (2d) ro22 (C.C.A. 3d 1934) (buying up bonds); In re Electric Public Service Co., 9 F. Supp. 128 (Del. 1934) (prior proceedings upheld); Provident Mut. Life Ins. Co. v. University Ev. Lutheran Church, 9o F. (2d) 992 (C.C.A. 9th 1937) (no plan). See Gerdes, "Good Faith," in the Initiation of Proceedings under $\S 77 \mathrm{~B}$ of the Bankruptcy Act, 23 Geo. L. J. 4I8 (I935). Note, Judicial Discretion of Petitions Filed under $\S 77$ B, 48 Harv. L. Rev. 283 (1934). 
promisor of the contract made for his benefit. ' That there is no "privity" between the third party and the promisor is one reason for the refusal of an action to the third party. ${ }^{2}$ Another is that the English rule of consideration requires that consideration shall move from the promisee to the promisor. ${ }^{3}$

On the other hand, the accepted rule in the United States is that the third party has a cause of action against the promisor. ${ }^{4}$ In this country the rule as to consideration did not raise the same difficulties as were raised by the English rule,, 5 and recovery was more easily granted. Various theories have been advanced to account for the recovery generally allowed. It has been suggested that, in the creditor-beneficiary cases at least, the promisee becomes a surety on his debt to the third party, while the promisor is the principal debtor. ${ }^{6}$ Another explanation is that the creditor's right is in the nature of an equitable execution against a valuable asset of his debtor.?

For the most part, however, there is little attempt at rationalization of the basis of recovery. A test has been developed, which is expressed by the statement that the third party may recover on the contract if it was made for his benefit ${ }^{8}$ and if the parties intended to benefit him. ${ }^{9}$ This test, as automatically applied, hides the complexities of the situation.

The rationale behind the "benefit" test is based upon the same legal philosophy which allows the enforcement of ordinary contracts. Contract liability, as distinguished from tort liability, has been voluntarily undertaken..$^{x 0}$ The law attempts to enforce the results which the parties intended to bring about. If an obligation has been voluntarily undertaken which comprehends benefits to and rights in a third party, it seems entirely just that such third party should be able to enforce the promise. If the parties "intended" to "benefit" a third person, then the performance agreed upon by the promisor, for which he has received consideration, includes doing something for the third party, and such per-

x Corbin on Anson, Principles of the Law of Contracts 325 (3d Am. ed. 19rg); 2 Williston, Contracts $\$ 360$ (rev. ed. 1936 ).

2 Rice v. Eason, 4 B. and Ad. 433 (1833).

3 Corbin, op. cit. sutpra note $x$, at 337 .

${ }_{4}$ Rest., Contracts $\S \mathrm{I}_{3} 6$ (I932); Corbin, op. cit. supra note $\mathrm{I}$, at 335 ; Williston, op. cit. supra note $\mathbf{I}$, at $\S 36 \mathrm{r}$.

5 Note 3 , supra.

${ }^{6}$ John Deere Plow Co. v. Tuinstra, 47 S.D. 555, 200 N.W. 6I (1924).

${ }^{7} 3^{8}$ Harv. L. Rev. 502 (1925).

8 Howard v. United States, I84 U.S. 676 (1902); Fidelity \& Deposit Co. v. Rainer, 220 Ala. 262, I25 So. 55 (I929); Lawrence v. Oglesby, I78 Ill. I22, 52 N.E. 945 (I899); Brill v. Brill, 282 Pa. 276, I27 Atl. 840 (I925).

9 Pennsylvania Steel Co. v. New York City R.R., I98 Fed. 72 (C.C.A. 2d I9x2); German Alliance Ins. Co. v. Home Water Supply Co., 226 U.S. 220 (I9I2); Hendrix Mill \& Lumber Co. v. Meador, $228 \mathrm{Ky} .844$, 16 S.W. (2d) 482 (1929).

so Fuller and Perdue, The Reliance Interest in Contract Damages, 46 Yale L. J. 52, 57 (1936). 
formance should be enforced at the suit of the third party. As in suits by the original promisee, the limits of the undertaking of the parties are controlling, and so the rights of the third party are limited by the terms of the promise. ${ }^{\text {II }}$ The benefit test, then, is a way of ascertaining the intention of the parties. A more accurate way of stating this intention is to say that the parties intended that performance be rendered to the third party.

It is suggested that some such test as this is actually in the contemplation of courts which use the more simple but less accurate "benefit" test. The right of the donee beneficiary was one of the earliest to be recognized, ${ }^{12}$ since it was very clear that the promisee intended to benefit him. ${ }^{x^{3}}$ In the donee beneficiary cases, relationship by blood or marriage, at first a requirement, came to be considered an evidential fact tending to prove that benefit was intended. ${ }^{x 4}$ The courts at first experienced some difficulty in applying the benefit test to the creditorbeneficiary cases, since it was difficult to conceive of the promisee's wanting to "benefit" his creditor, in the sense of his experiencing towards his creditor a feeling of altruisim. ${ }^{55}$ Although the benefit test is still used, the right of the creditor-beneficiary to recover is now well established. ${ }^{16}$ Approaching this problem from the point of view of the intention of the parties, rather than from the "intent to benefit" angle, would obviate this difficulty. Although the promisee may have hated his creditor, and would never wish to "benefit" him, still he desired and intended, for strong and good reasons, that performance should be rendered to the creditor. An established rule is that an incidental beneficiary cannot recover on a contract, since the parties did not intend to benefit him. ${ }^{\mathrm{I}} \mathrm{7}$ This is simply another way of saying that the parties to the contract had no intention of vesting rights in the contract in the alleged beneficiary.

The Illinois cases consistently adopt the "intent to benefit" test of the right of the beneficiary. ${ }^{18}$ The following is a typical statement: "It is well-settled law in this state that where one person for a valuable consideration makes a promise to another for the benefit of a third person, such third person may maintain an

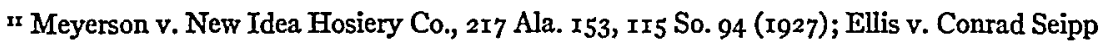
Brewing Co., 207 Ill. 29r, 69 N.E. 808 (1904); Vial v. Norwich Union Fire Ins. Society, 257 IIl. 355 , 100 N.E. 929 (1913).

${ }^{12}$ Williston, op. cit. supra note $\mathrm{I}$, at $\S 357$.

${ }^{3}$ It has been suggested that the reason the donee-beneficiary is allowed to recover is that a complete to gift has been made to him. Whittier, Contract Beneficiaries, 32 Yale L.J. 790 (1923).

${ }_{44}$ Corbin, op. cit. supra note $\mathrm{r}$, at 337 .

${ }^{25}$ On this point, see Professor Corbin's discussion, Third Party Beneficiaries of Contractors Surety Bonds, 38 Yale L. J. I (I928).

${ }^{16}$ Corbin, op. cit. supra note I, at 356; Rest., Contracts $\$$ r33 (1932).

17 Corbin, op. cit. supra note $\mathrm{I}$, at 355; Williston, op. cit. supra note $\mathrm{I}$, at $\$ 402$ (r932).

${ }^{18}$ Dallum v. Birdsall, 66 Ill. 378 (1872); Eddy v. Roberts, I7 Ill. 504 (1856); Hartford Fire Ins. Co. v. Olcott, 97 Ill. 439 (r88r); Carson, Pirie, Scott \& Co. v. Parrett, 346 Ill. 252, I78 N.E. 498 (r93 $\mathrm{r}$ ). 
action upon it. It is not necessary that there should be any consideration moving from the person for whose benefit the promise is made or that there should be any privity between them." "'xg Under this theory, recovery has been granted or denied in a variety of situations. In one case, a hotel corportaion being without funds to furnish the hotel in accordance with the requirements of a trust deed securing the bond issue, the bond underwriters and the president and treasurer of the hotel made a contract with the hotel corporation agreeing to pay promptly for furnishings if the hotel did not pay. The plaintiff, having failed to receive payments from the corporation for linens furnished, sued the defendants on the contract mentioned. It was held that the plaintiff was entitled to judgment as a third party beneficiary of that contract. ${ }^{20}$ It would seem that in this case the right of action was actually based upon a promise to render performance to a third party. In another Illinois case ${ }^{2 x}$ use was made of the third party beneficiary doctrine in a somewhat unusual way. In that case, the plaintiff sued her brother on a promise made by him to their dying father, that he would pay the plaintiff a certain sum out of the money the father left him in his will. There was a judgment for the plaintiff, on the theory that the promise was made for her benefit. This type of case has been more customarily solved by the imposing of a constructive trust on the defendant.22

Where A buys land or goods from $\mathrm{B}$, and as part of the purchase price promises to pay a debt which $B$ owes to $C$, recovery is generally allowed $C .^{23}$ Nor does such a contract come within the Statute of Frauds section requiring that a promise to pay the debt of another be in writing. "If the promise is in the nature of an original undertaking to pay a debt to a third party, and is founded on valuable consideration received by the promisor himself, it is not within the provisions of the statute, and need not be in writing to make it valid and binding-it will be regarded in the light of a contract for the benefit of a third party, upon which said third party may found an action for the breach."25

A special aspect of this problem is presented by a familiar type of case which arises when a grantee of the mortgagor assumes the mortgage debt. There must be an actual promise by the grantee that he will undertake the obligation owed

${ }^{99}$ Wollenberger v. Hoover, 346 Ill. 5II, 594, I79 N.E. 42, 75 (I93I).

${ }^{20}$ Carson, Pirie, Scott \& Co. v. Parrett, 346 IIl. 252, I78 N.E. 498 (193x). See also Chicago Title and Trust Co. v. Central Trust Co. of Illinois, $3 x_{2}$ Ill. $396, x_{44}$ N.E. $x 65$ (I924) (in which credit for a cause of action in a third party beneficiary was allowed in an accounting); and Torpe v. Jahn, I77 III. App. 85 (rgr3) (promise, for consideration, to pay brokerage fee to third party, enforced at suit of the third party).

${ }^{2 x}$ Lawrence v. Oglesby, I78 IIl. I22, 52 N.E. 945 (I899).

22 Bogert, Trusts $\S 47 \mathrm{I}$ (x935).

${ }^{23}$ Snell v. Ives, 85 Ill. 279 (I877); Easter v. Newbury, 170 Ill. App. 494 (I9I2); Merchants

Loan \& Trust Co. v. Ummach, 228 III. App. 67 (rg23).

${ }_{24}^{4}$ Eddy v. Roberts, I7 Ill. 504, 508 (1856); Wilson v. Bevans, 58 Ill. 232 (187x).

${ }_{25}$ Wilson v. Bevans, 58 IIl. 232, 234 (r87r). 
by the promisee to the mortgagee..$^{26}$ Webster $v$. Fleming, ${ }^{27}$ in allowing the mortgagee to recover from the promisee, uses the typical "intent to benefit" approach. Another case, also allowing recovery, comes nearer to the "direct rights" test: "The appellant assumed the payment of the specified portions of the incumbrance on the property as a part of the purchase money he was to pay. He thereupon became personally liable to the holder of the notes as fully as if the agreement to pay such portion of the purchase money had been made directly to the holder of the notes for adequate consideration." ${ }^{28}$ The language in Daub v. Englebach ${ }^{29}$ is still more forcefully in the direct rights tradition. A slightly different problem arises when the land is conveyed to a purchaser who does not assume the mortgage, who in turn conveys to a purchaser who does assume. Consistently with the direct rights test, recovery in this situation has been allowed in Illinois. ${ }^{30}$

In most of the cases just discussed, the intent to benefit, or the intent that performance shall be rendered to, the third party, is fairly clear. Such intent is sometimes more difficult to find in cases in which laborers or materialmen are suing on a bond given by a contractor to the owner of a building project. Recovery is granted where the laborers and materialmen are specifically named in the bond, ${ }^{3 x}$ since the intent to benefit them in that situation is considered clear. Where the promise on the part of the contractor was merely that he would "pay and discharge from said premises all liens for material, labor, or otherwise which may accrue on account of said building contract," recovery was denied on the grounds that the promise was made for the benefit of the owner rather than for that of the materialmen..$^{32}$ In Searles v. City of Flora ${ }^{33}$ the contract between the city and the contractor provided that the contractor should pay for all materials and labor, and the contractor's bond was conditioned on his "well and truly performing" all things set forth in the contract. In spite of this, recovery was denied the materialman-plaintiff, on the theory that the bond was not for his benefit, but for the benefit of the city, insuring the completion of the work within the period of time called for in the contract. The decision indicates the limitations of the "benefit" theory, since the performance called for in the contractor's promise included payment of money to the materialmen. The same limitation is indicated in two other cases where recovery was denied, one in which the promise was to "pay all bills," 34 and one in which the contractor promised to "furnish all labor, materials and tools necessary to

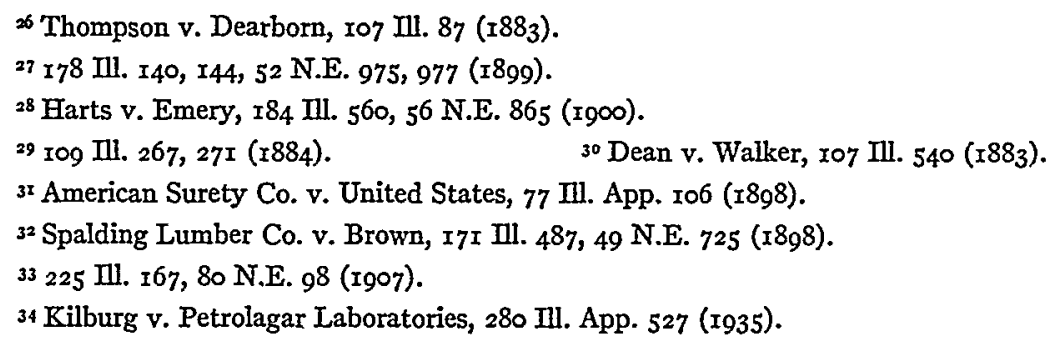


execute the entire work." 35 When the suit by the materialman or laborer is against a surety of the contractor, it has been argued that the promise should be construed in favor of the surety whenever possible, because the obligation of a surety should not be strictly construed..$^{36}$ On the other hand, Arnold suggests ${ }^{37}$ that the obligation should be construed against the surety wherever possible, since the surety has been compensated to take the risk, and since he is better able to bear the risk than are the laborers and materialmen. The problem of distinguishing between donee and creditor beneficiaries, and the recovery which should be allowed to them, mentioned above, is also met in the contractor's bond cases. It has been said that a distinction should be made depending on whether the bond was given to a public or a private owner. ${ }^{38}$ The distinction was advocated because the plaintiffs had a right to a lien on the property of a private owner, whose intention might be to benefit himself by the contractor's bond; while they had no lien on public property and the promise was therefore considered to be for their benefit. Hence recovery was sometimes denied in the former case. ${ }^{39}$ However, recovery is generally allowed whether the bond was given to a private or a public owner. $4^{\circ}$

One characteristic of the contractor's bond cases is that the beneficiary is not specifically identified in the contract, and yet is allowed to recover. This is also, illustrated in the case of Bristow v. Lane, ${ }^{4 \mathrm{I}}$ in which the promise was to pay the creditors of the promisee in certain cities. Plaintiffs were allowed to recover upon showing that they were within the class mentioned. Thus, if the intention of the parties is sufficiently clear that performance shall go to a certain class of persons, persons within this class should be allowed to recover, although they are not mentioned by name. In another case ${ }^{42}$ the plaintiff was allowed to recover where the "surrounding circumstances" were sufficiently clear to indicate that he was to be the beneficiary.

Although a beneficiary unidentified at the time the contract was made may recover, there is no recovery when no intent to benefit a third party can be found. The recipient of an erroneous telegram sued the Western Union Telegraph Co. for damages caused by a mistake in the message, on the theory that he was the beneficiary of the contract between the sender of the telegram and the defendant. Recovery was denied on the ground that the contract was not made for the benefit of the plaintiff. ${ }^{43}$ Recovery was also denied in a case in

3 City of Sterling v. Wolf, I63 Ill. 467, 45 N.E. $2 \times 8$ (I896).

${ }^{36}$ Alexander Lumber Co. v. Aetna Accident Co., 296 IIl. 500, 504, I29 N.E. 87I, 873 (I92I).

37 Arnold, The Compensated Surety, 26 Col. L. Rev. x7r, r73 (rg26).

${ }^{38}$ Williston, op. cit. supra note I, at ro8g.

${ }^{39}$ National Surety Co. v. Brown-Graves Co., 7 F. (2d) 9I (C.C.A. 6th 1925); Maryland Casualty Co. v. Johnson, 15 F. (2d) 253 (D.C. Mich. 1926).

40 Williston, op. cit. supra note I, at ro85; Campbell, Protection of Laborers and Materialmen under Construction Bonds, 2 Univ. Chi. L. Rev. r, 201 (I930).

${ }_{42}$ 2I III. 194 (I859).

$4^{2}$ Hartford Ins. Co. v. Olcott, 97 Ill. 439 (r88r).

${ }_{43}$ Western Union Tel. Co. v. Du Bois, 128 Ill. 248, 2r N.E. 4 (I889). 
which suit was brought against the defendant railroad company by senders of mail which had been lost through the negligence of the railroad company. ${ }^{44}$ The court denied that the contract was made for the benefit of the senders of the mail, and also stated that there was no privity of contract between the plaintiff and the defendant.

We have seen that the benefit test is in most instances actually an unconscious application of the direct rights theory, and that the latter theory is consistent with the results actually reached in the cases. 45 There remain to be examined certain specific results which should be reached under the direct rights test, and which may not be reached under the benefit theory. If the third party has a direct right against the promisor, it is arguable that this right will not be affected by an action subsequent to the promise, by the promisee. It has been said that this is the general rule..$^{6}$ In Bay $v$. Williams ${ }^{47}$ the purchaser of the mortgaged premises who had assumed payment of the mortgage was liable to the mortgagee, although he had received a release from the mortgagor. The court said:

The principle upon which this court has acted is, that such a promise invests the person for whose use it is made with an immediate interest and right as though the promise had been made to him. This being true, the person who procures the promise has no legal right to release or discharge the person who made the promise, from his liability to the beneficiary. Having the right, it is under the sole control of the person for whose benefit it is made-as much as if made directly to him..$^{8}$

In this case, the contract was executed. It was held in Hartman ข. Pistorius ${ }^{49}$ that in the case of a contract wholly or partly executory on both sides, a third party beneficiary who at one time apparently had a good cause of action is defeated by the cancellation of the contract by the parties thereto. While the distinction made between an executory and an executed contract is sound, there is a dictum which unnecessarily casts some doubts upon the decision in Bay v. Williams.

Another test of the "direct rights" theory is whether or not the third party can sue on a contract under seal. If he has a direct right, he should be able to sue on such a contract. Although an early Illinois case held that the beneficiary could not sue on such a contract, ${ }^{50}$ and although there are conflicting decisions, ${ }^{5 \mathrm{x}}$

44-A.tna Life Ins. Co. v. Ill. Central R.R., 365 Ill. 303, 306, 6 N.E. (2d) I89, I9I (I936). ${ }^{45}$ See Corbin, op. cit. supra note $15 ;$ at 8. $4^{8} \mathrm{Id}$. at 87 .

4 Corbin, op. cil. supra note $\mathrm{T}$, at $35 \mathrm{r}$.

47 x 2 IIl. 9I, I N.E. 340 (I884). ${ }^{49} 248$ Ill. 568,94 N.E. I3I, I33 (Igrr). ${ }^{50}$ Moore v. House, 64 Ill. I62 (I872).

${ }_{5 x}$ Dean v. Walker, I07 ㅍll. $54 \circ$ ( 1883 ), held that a third party could sue on a sealed instrument, after the passage of III. Rev. Stat., $x 874, \S x 9$, which provided that contracts under seal could be sued upon in the same manner as simple contracts; Harms v. McCormick, $\mathrm{I}_{32} \mathrm{Ill}$. ro4, 22 N.E. 5II (1889), contradicted this ruling, and stated that the Dean case was mere dictum on this point. Webster v. Fleming, 178 Il. I40, 52 N.E. 975 ( 1899 ) then held that a third party could sue on a sealed contract, and said that the part of the Harms case inconsistent with the Dean case was mere dictum. 
the final authority seems to be that the third party may sue on a contract made for his benefit, although it is under seal..$^{22}$

It has been suggested ${ }^{53}$ that the grantee of the mortgagor who assumes payment of the mortgage is simply promising indemnity to the mortgagor. This rule might raise some doubts about the direct rights theory, although theories of construction or mistake may be used to reach the same result. Illinois has expressly repudiated the suggestion. ${ }^{54}$

The creditor-beneficiary cases raise the question of whether or not the promisee may sue on the contract made for the benefit of the third party. Even though the beneficiary has a direct right against the promisor, the promisee should also have a cause of action. It has been suggested that in the donee beneficiary cases, the promisee may not sue, since his interest in the contract is nominal. ${ }^{55}$ He should have the right to sue for breach of the promise made to him, however, if he chooses to bring suit for nominal damages only. The question of the amount of damages to be recovered is entirely separate from the question of whether or not a right exists which should be vindicated. And in the case of a promisee who has procured the promise for the purpose of insuring the discharge of some obligation which he owes, it is recognized that such a promisee may sue the promisor for breach of the contract. ${ }^{56}$ This right exists whether or not the promisee has actually had to pay his creditor. In the case cited the father of the plaintiff had assumed a debt of the plaintiff's. On the death of the father, the son brought suit for a declaratory judgment that the administrator of his father's estate be ordered to pay the debt. Judgment was rendered for the plaintiff, the court saying:

By the conveyance and contract, the liability of Seth Ingram [father] for the amount of the mortgage debt, with interest thereon, was absolutely fixed and determined, and that liability existed for the benefit of Samuel Ingram, who had originally executed the mortgage, and also in the interest of Hodge, the mortgagee, who had a right to enforce the mortgage as against Seth Ingram. By his death, his estate became liable to pay the same; and, had Samuel Ingram paid the mortgage debt, he would have a claim against the estate of his father to recover the same.57

Aside from the more common situations involving the use of the third party beneficiary theory, there are other situations in which it has been used less frequently. The theory has been applied to some extent in cases involving the manufacturer's liability to the consumer.$^{58}$ In many jurisdictions, the tort liability of the manufacturer is sufficiently well-established to make the use of

52 Torpe v. Jahn, I77 Ill. App. 85 (I9I3).

53 Note 7 , supra.

54 Bay v. Williams, II 2 Ill. 9I, 96, I N.E. 340, 342 (I884).

ss Corbin, op. cit. supra note $\mathrm{I}$, at $35 \mathrm{r}$.

${ }^{56}$ Meyer v. Hartman, 72 Ill. 442 (I874).

${ }^{57}$ Id. at 444 .

${ }^{58}$ Ward Baking Co. v. Trizzino, 27 Ohio App. 475, I6I N.E. 557 (r928); Mazetti v. Armour \& Co., 75 Wash. 622, 135 Pac. 633 (Igr3); Coca-Cola Bottling Works v. Lyons, I45 Miss. 876, III So. 305 (I927). 
the warranty attack unnecessary.59 Since the tort liability of the manufacturer is not equally well-established in Tllinois, ${ }^{60}$ it might be desirable to use the contract theory in the solution of this problem. This theory does not seem to be a particularly happy one, however, as applied to a manufacturer's liability, since it is difficult to work out an adequate promise on the part of the manufacturer, and because in most jurisdictions it is possible to stipulate against implied warranties.

Use has been made in the field of labor law of the fact that the third party beneficiary is usually allowed to recover. Suits brought by members of labor unions, on the theory that they were beneficiaries of the contract between the labor union and the employer have been sustained.65 The theory was approved in Tllinois, ${ }^{6_{2}}$ the court saying, "In the instant case appellee made a valid, written contract with the Milk Wagon Drivers' Local Union. Appellant expressly assented to its terms, entered into a valid contract of employment with the appellee with reference to its provisions, and was one of the parties intended to be benefitted thereby." $6_{3}$ It is reasonable to suppose that the employer, in signing the contract with the union, intended (or recognized) that rights would accrue to the individual laborers, ${ }^{64}$ but for the purpose of adequately protecting the public interest in such contracts, enforcement should not be confined to theories developed for purely private contracts.

59 Harper, Torts 245 ff. (r933); 4 Univ. Chi. L. Rev. 46I (I937); 72 U. of Pa. L. Rev. 52 (rg23); Feezer, Manufacturer's Liability for Injuries Caused by His Products, 37 Mich. L. Rev. I (I937).

${ }^{60}$ Rotche v. Buick Motor Co., 358 IIl. 507, 193 N.E. 529 (1935); Bowman v. The Woodway Stores, 345 Ill. IIo, x77 N.E. 727 (x93I).

6x Rentchler v. Missouri Pac. R.R. Co., I26 Neb. 493, 253 N.W. 694 (1934); Yazoo \& M.V. R. Co. v. Sideboard, I6x Miss. 4 , I33 So. 669 (I93I); Gulla v. Barton, I64 App. Div. 293, I49 N.Y. Supp. 952 (I9r4); Moody v. Model Window Glass Co., 145 Ark. 197, 224 S.W. 436 (1920); Blum Co. v. Landau, 23 Ohio App. 426, I55 N.E. I54 (I926).

62 Dierschow v. West Suburban Dairies, 276 Tll. App. 355 (I934).

${ }^{6} 3$ Id. at 372 .

64 Rice, Collective Labor Agreements in American Law, 44 Harv. L. Rev. 572 (I93I); Fuchs, Collective Labor Agreements in American Law, ro St. Louis L. Rev. I (I924). 